$-$

$-1$

$(8)$

s.

政

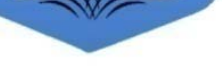

GLOBAL JOURNAL OF HUMAN-SOCIAL SCIENCE: E

ECONOMICS

Volume 16 Issue 2 Version 1.0 Year 2016

Type: Double Blind Peer Reviewed International Research Journal

Publisher: Global Journals Inc. (USA)

Online ISSN: 2249-460X \& Print ISSN: 0975-587X

\title{
Reaping Demographic Dividend in Bangladesh: Challenges and Prospects
}

By Mallika Roy \& Md. Safiullah Kayesh

University of Chittagong

Abstract- Demographic change in Bangladesh is opening up new economic opportunities. As in many countries, declining infant and child mortality helped to spark lower fertility, effectively resulting in a temporary baby boom. As this cohort moves into working ages, Bangladesh finds itself with a potentially higher share of workers as compared with dependents. If working-age people can be productively employed, Bangladesh's economic growth stands to accelerate. Theoretical and empirical literature on the effect of demographics on labor supply, savings, and economic growth underpin this effort to understand and forecast economic growth in Bangladesh. Policy choices can potentiate Bangladesh's realization of economic benefits stemming from demographic change. Failure to take advantage of the opportunities inherent in demographic change can lead to economic stagnation.

Keywords: demographic dividend, population transition, investment, vocational education.

GJHSS-E Classification : FOR Code: 910102

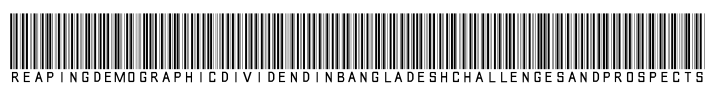

Strictly as per the compliance and regulations of:

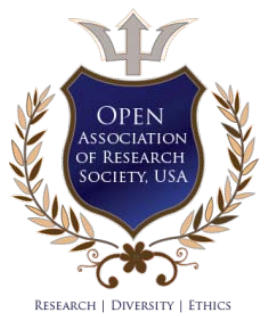

(C) 2016. Mallika Roy \& Md. Safiullah Kayesh. This is a research/review paper, distributed under the terms of the Creative Commons Attribution-Noncommercial 3.0 Unported License http://creativecommons.org/licenses/by-nc/3.0/), permitting all noncommercial use, distribution, and reproduction in any medium, provided the original work is properly cited. 


\title{
Reaping Demographic Dividend in Bangladesh: Challenges and Prospects
}

\author{
Mallika Roy ${ }^{\alpha} \&$ Md. Safiullah Kayesh ${ }^{\sigma}$
}

\begin{abstract}
Demographic change in Bangladesh is opening up new economic opportunities. As in many countries, declining infant and child mortality helped to spark lower fertility, effectively resulting in a temporary baby boom. As this cohort moves into working ages, Bangladesh finds itself with a potentially higher share of workers as compared with dependents. If working-age people can be productively employed, Bangladesh's economic growth stands to accelerate. Theoretical and empirical literature on the effect of demographics on labor supply, savings, and economic growth underpin this effort to understand and forecast economic growth in Bangladesh. Policy choices can potentiate Bangladesh's realization of economic benefits stemming from demographic change. Failure to take advantage of the opportunities inherent in demographic change can lead to economic stagnation.
\end{abstract}

Keywords: demographic dividend, population transition, investment, vocational education.

\section{INTRODUCTION}

T he fiscal and economic crises enveloping many of the world's wealthiest nations-from Italy and Japan to the United Kingdom and the United States-have brought to light the economic challenges arising from tectonic shifts in demography in the developed world.

During the demographic transition, sharp declines in fertility lead to large changes in a population's age structure. Smaller birth cohorts decrease, youth dependency ratios and mechanically increase output per capita if output per worker and the labor force participation rate of the working-age population remain unchanged. This generates the demographic dividend. In developing societies mortality rates decline followed by a fall in fertility rates, inducing a change in the age structure. As a result of declining population growth, there is a bulge in working-age population and shrinking dependent population that can allow for faster rates of economic growth when combined with effective policies and markets.

The effect of changes in the age structure of a nation upon its economy has been studied for decades (Coale and Hoover, 1958; Easterline, 1967; Simon, 1981; Ehlrich and Ehlrich, 1990, Bloom, Canning and Malaney, 2000; Mason, 2005). The underlying theory says that demographic dividend puts a positive impact

Author a: Assistant Professor, Department of Economics, University of Chittagong.

Author $\sigma$ : Lecturer, Department of Economics, University of Chittagong. e-mail: kayes.cu.bd@outlook.com on a nation's economic development and that in high fertility societies; fertility reduction is a potentially powerful tool to reduce poverty (Eastwood and Lipton, 1999; Mason and Lee, 2004).

Amongst many South and Southeast Asian countries, Bangladesh enjoying great success with family planning programs along with the remarkable improvement in health status, India with impetus on basic and secondary education and technology sector, Thailand's drive for better health, turned out highly thriving in liberalizing their markets and attracting foreign investments (Bloom, Canning, and Sevilla, 2003).

\section{Literature Review}

Roy et al. (2014) examined the prospects of demographic dividend in India. The census projection report shows that the proportion of working-age population between 15 and 59 years is likely to increase from approximate 58\% in 2001 to more than 64\% by 2021. Such a trend would make India one of the youngest nations in the world.

Prof. Dora Thompson et al. (2012) stated that for an ambitious target of inclusive growth it is essential that India capitalizes on her demographic dividend effectively on a sustainable basis. The research paper elucidates and finds out as to how the phenomenon of inclusive growth and a demographic dividend of India are complementary to each other.

Prince TC (2014) explained that there is a positive correlation between the size of working age population and economic productivity, but the effectiveness of both requires a consistent set of policy initiatives based on national priority. The following areas must require a special attention from the side of the government including health sector, education sector, investments in backward areas, and research \& development initiatives on areas of public importance, creation of employment opportunities, extent foreign direct investments (FDI) in traditional sectors and ensure women participation in formal employment sectors.

David E. Bloom, David Canning and Jaypee Sevilla (2001) on a working paper examined the relationship between population change and economic development in particular regions of the world: East Asia; Japan; OECD, North America and Western Europe; South-central and Southeast Asia; Latin America; Middle East and North Africa; Sub-Saharan Africa; and Eastern Europe and the former Soviet Union. 
Finally, it discussed the key policy variables that combined with reduced fertility and increases in the working-age population, have contributed to economic growth in some areas of the developing world.

Ian Pool (2007) highlighted important features of the transition process too much neglected by economists.

Ms. Hareem Tariq \& Ms. Mani A Malik (2012) focused on the issues involved in taking advantage of the demographic dividend and how to overcome these issues, the strategies involved in optimally utilizing the present situation which would not only ensure that there will be a rise in national income but also, it would be an overall development of the nation and upliftment of the standard of living of the society. This paper highlighted the key development areas on which India was already successful and the areas in which it was putting efforts to develop a force.

Policy brief by J. Gribble et al. (2012) explained the connection between the demographic dividend and investments in voluntary family planning; highlighted Africa's particular challenge in achieving a demographic dividend and the need for immediate action; and underscores the investments in health, education, and gender equity, as well as subsequent economic policies, that are needed to open and take advantage of this window of opportunity.

\section{ili. Need for the Study}

Bangladesh is a highly densely populated country with the population growth rate 1.6 percent in 2014.Population growth is always considered as a serious concern but sometimes demographic transition brings potential economic benefit. Most of our population directly or indirectly depends on agriculture and their per capita income in agriculture is very low. We have to bring diversification in agriculture and reduce our population dependency on agriculture in order to substantially increase per capita incomes in agriculture. Especially we have to give an emphasis on industrial led agriculture. People in our country are working in the unorganized sector getting lower incomes, little health protection, and no incentives. Hence, if Bangladesh needs to accelerate its phase of development, one important possibility is by increasing investment in human capital and another creates an environment in which there are fewer people less on agriculture, creation of productive jobs in the organized sector, enhancing entrepreneurship, foster investments while improving strategies for increasing the productivity in agriculture. We require more flexible labor markets, especially women literacy, greater women participation in all socio-economic aspect, a broad attitude about women working, higher rates of female labor force participation, a healthier population, improved infrastructure and technological advancement. In brief,
Bangladesh needs to foster decades of inclusive growth. Now, the challenge for Bangladesh is how to reap the benefits of the demographic dividend. In this paper, we have attempted to explain the relationship between demographic dividend and its dependency on the socio-economic policy framework being adopted and implemented by Bangladesh government.

\section{OBJECTIVES}

- To critically evaluate the demographic trends in Bangladesh based on the past, present and projected data.

- To identify what challenges are associated with inclusive growth for attaining demographic dividend.

- To find out the effective measures to ensure maximum mileage that can yield demographic dividend.

- To get a clear idea about the future prospects generated by the demographic dividend.

\section{Research Method}

In this paper, we review demographic trends in Bangladesh of the past, present and projected. Our main focus is on the years 2020-2025. We begin by looking at the characteristics of demographic transitionage dependency ration, data on population growth and its components (births, deaths, and the international migration) and the age structure and the sex composition of the population. We conclude by discussing the results of these demographics. In this paper, we mostly use data from the United States Census Bureau, International Data Base (IDB), and World Bank, newspapers, websites and other various secondary sources.

Thus, the study has been divided into three parts to cover the different aspects of demographic dividend:

- Data analysis and key findings

- Explore the socio-economic challenges

- Policy recommendation

To fulfill the objectives various variables have been selected such as investment, Gini coefficient, income, female labor forces, participation rate, crude birth rate, crude death rate, life expectancy, age dependency ratio and population growth rate along with the potential parameter demographic factors.

\section{Vi. Key Findings: The Demographic Transition in Bangladesh}

We have got the key findings by analyzing the following demographic indicators.

a) Age dependency ratio (\% of working- age
population) in Bangladesh
According to the World Bank definition, Age dependency ratio is the ratio of dependents-people 
younger than 15 or older than 64-to the working-age population - those ages 15-64.

If we analyze the graph 1and 2, then we will see that the in the 1970s the growth rate of dependent population was higher than the growth rate of working age population. In the early 80 s, we have seen a huge shift in the growth rate trends, with more working-age population than the dependent population.

Over the time, the dependency ratio is gradually declining. This states that we have already entered in the demographic transition phase and this has created a window of economic opportunity. Age dependency ratio in Bangladesh was last measured at 53.68 in 2014 which was 69.13 in 2000, according to the World Bank. Now the question is whether Bangladesh will be able to realize the benefit of the demographic dividend or loss the windfall, will rely on it's accepting the challenges in providing and implementing proper policies.

\section{b) Population growth and its Components}

Bangladesh annual population growth rate in the year 2013-2014 is $1.59 \%$ as per US census bureau 2014. In Table 1 it is very clearly stated that Bangladesh is in the process of demographic transition. If we look at the birth rates it has drastically reduced to 21.6 from 31.1 per 1000 population and the death rates have decreased to 5.6 from 7.4 thereby reducing the number of dependents on the working age population.

As per table 2, the gap between births and deaths is gradually narrowing in Bangladesh, resulting in slower population growth rate has been declining and expected the rate will be 1.4 percent in 2025 .

\section{- Crude Birth Rates (CBR)}

Crude birth rate indicates the number of live births occurring during the year, per 1,000 population estimated at midyear. During the 1995-2025 the CBR in Bangladesh is projected to decrease smoothly from 32 per 1,000 to 18 per 1,000 . The number of births in a country depends on the average number of births per woman of childbearing age and the number of women in this age range. If the number of women of childbearing age is increasing, the number of births can increase even if the number of births per woman is decreasing-a phenomenon termed as "population momentum". We now discuss each of these in turn. The total fertility rate (TFR), the average number of lifetime births per woman (or more precisely, the number of births a woman would have in her lifetime if at each age she experienced the age-specific fertility rates of that year), is a measure of fertility that is not affected by the number of women of childbearing age in the population. The TFR is thus considered a better measure than CBR for comparing fertility levels between countries or time periods. The census bureau's IDB estimates that the TFR in Bangladesh will decrease very gradually to "replacement level"- the level needed for population stabilization in the long run (approximately 2.1 children per woman) by 2025.

\section{- Crude Death Rates (CDR)}

Crude death rate indicates the number of deaths occurring during the year, per 1,000 population estimated at midyear (World Bank). It is strongly affected by the age composition of a population. Bangladesh Crude death rate (CDR) is projected to remain stable at 6 per 1,000 from 2014 to 2025.

\section{c) Age-Sex Structure of the Population}

Population pyramids are normally used to depict the age-sex structure of a population of a certain country. A nation with high fertility rates, the pyramids are formed with a wide base with a large number of young age population and narrow bands near the top representing an older population which are near the end of their natural lifespan. In Graph 3, 4, 5 and 6 we show population pyramids for Bangladesh for the year 2000, 2014, 2025 and 2050. The Bangladeshi age-sex structure in 2000 is a good example of classical pyramid shape. The pyramid shape of the year 2014 has a thicker base than the year 2000. Now, due to fewer births as we go forward, the base (age 0-4) of the pyramid for Bangladesh in 2025 is not as wide as it for 2000 , but above age 20 the bars are all much wider than they are now for those age groups. As a result during this period the proportion of the population in the labor force ages is increasing, provides a one-time 'demographic dividend 'for investing heavily in human resource development. As measured by the proportion the population in the labor force ages (here defined as 15-59) this window projected open widely in Bangladesh over the next 10-20 years, which is a relatively short period. The labor force growth would slow down and level off by 2050 and decline (Graph 6) and labor force growth will occur after a certain period of 2025. With declining fertility and rising life expectancy, the population aged $0-14$ and $0-60+$ will be approximately equal by 2050. After this point in time, old-age dependency will exceed youth dependency.

However, now it is time to bank on Bangladesh's demographic dividend. Census data 2014 shows that youth group is now sharpest at 15-24 age groups, as its youngest and oldest age group begin to slender. Now the working age population is $53.68 \%$ of the total, as against $69.13 \%$ in 2000 .

\section{Vil. Prerequisite of Demographic Dividend in Bangladesh}

Economic theories tell us that land, labor, capital, entrepreneurs, science and technology, health, environment have to be used properly for the maximum returns for the development of the economy. The demographic transition created surplus labor and 
extensive investment is required to utilize surplus labor. For transferring the demographic transition into a demographic dividend, following prerequisites have to be fulfilled.

a) Maximum return from arable land by crop diversification and using high yield crops.

b) Ensure large scale and continual long-term investment in the manufacturing sector. Since laborintensive manufacturing sector will generate capital and absorb labor surplus.

c) Ensure sufficient institutional vocational training to meet the demand of efficient and skilled labor.

d) Female labor force participation should be increased with workstation security and others amenities.

e) More globalizing and more diversifying manufacturing units will increase earnings and persistent surplus which will help in capital formation.

f) Capital formation provides the momentum for an effective and efficient combination of factors of production to ensure sustainable economic growth.

g) Capital accumulation is necessary to provide labor with tools and implements of production. It is important enough to make a greater degree of specialization possible.

h) Maintenance internal political instability, so that the investment will not hamper and there is no wastage of capital.

i) Entrepreneurs play a vital role in economic development and key contributors to technological innovation and new job growth. Proper policy and incentives can boost up entrepreneurship.

j) Adopt latest science and technology in every sector so that local producers can compete in the global market with pricing power.

k) Per capita health expenditure should be proportionately increased with labor force growth.

I) Increase capacity building against the adverse environmental situation and problems due to global warming.

m) Strong transportation management and developing agriculture facilities and infrastructure that will help in marketing agriculture produce and agro-based industry.

n) Protect internal financial sector from global financial oscillation and establish safeguard against corruption.

Apart from capital and land, labor has to be deployed dexterously. If appropriate policies are not formulated, the demographic dividend might, in fact, be a cost, leading to unemployment and unbearable strain on education, health and old age security.

\section{Vili. Socio - Economic Challenges}

In this way of demographic transition Bangladesh face following socio-economic challenges which are also impediment toward getting the dividend.

\section{a) Investments by framing proper policy}

So far, Bangladesh has performed poorly in attracting FDI and is far from having achieved its potential could derive from foreign investment. The country lacks a coherent strategy on how to promote private investment, contribution to sustainable development, inclusive growth and job creation. A critical challenge for development is the poor quality of infrastructure. Insufficient supply of electricity has been a major bottleneck to investment over the past decade and transport is another crucial issue as well as.

\section{b) Poverty reduction and formation of pro-poor policy}

For poverty and extreme poverty reduction, in recent years, Bangladesh is being tagged globally as 'the land of impossible attainments. The World Bank announced in June 2013 that Bangladesh had reduced the number of people living in poverty from 63 million in 2000 to 46 million in 2010, despite a total population that had grown to approximately 150 million. The country has already achieved the targets meant for a hunger and poverty free society under the Millennium Development Goals (MDGs). Substantial progress in reducing poverty rates has been achieved, although doubt remains about the nature and extent of present levels of poverty. Microfinance programs benefit the moderately poor more than the destitute, and the impact can vary by income group. However considerable attempts are yet to be done. Important efforts are needed on the part of the government to formulate and implement growth strategies. The strategies should identically cover:

- Assisting NGO: The effectiveness of microfinance institutions in alleviating poverty is still in question and not free from debate. The government will need to assist NGOs in moving towards financial sustainability of the poor section.

- Export policy: Lack of policy inducement for agriculture and industry is an obstacle to the economic growth. The growth of exports and imports of capital goods and raw materials for industries has declined. (Unnayan Onneshan, 2014).

- Labour mobility: To make further inroads will require drawing more of the unemployed, underemployed and informal sector workers into more productive work, but in recent years, the formal sector has shown very limited absorption capacity.

- Social Safety Net (SSN): The coverage of SSN programs has been widening and the benefits are gradually expanding. In 2005, there were 11 SSN programs from which 13 percent of households 
received benefits. By 2010, the number of programs had increased to 30 and 25 percent of households received benefits (HIES 2011). Thirty percent of rural households received benefits from these programs compared with 9 percent of urban households. The budgetary allocation for SSNPs has been increasing but the percentage share of SSNPs in the national budget and GDP peaked in 2010-11 and then started to decline (Barkat et al. 2013). The coverage of the SSN programs is not universal and many researchers have argued that progress as not been satisfactory (CPD 2008; Raihan 2013)

- Urbanization: Bangladesh has surplus workers in the agricultural sector. If Bangladesh is to raise the overall level of productivity and incomes, productivity in the agricultural sector will need to rise and there will require being a movement of workers out of the agricultural sector. Urbanization will be a key driving force in the future. With all population growth (some 75 million over the 50 years 20112061, according to the medium UN projection) occurring in urban areas, it is crucial for Bangladesh to develop a comprehensive urban development strategy.

- Remittance: Temporary overseas labor migration has become an important matter in Bangladesh's employment situation. Like urbanization, it reflects the search for better opportunities by Bangladesh's burgeoning labor force. Labor migration affects Bangladesh's demography and development by delaying childbearing and contributing remittances.

c) Skill development programs of migrant workforce

Skill development and vocational training will help futures migrants get better and high paying jobs overseas, which in turn will bring greater volumes of remittances. In recent years, we have seen an impressive growth in remittances. Bangladesh earned a record of $\$ 15.31$ billion remittances in the fiscal year ended June 2015 and by the end of this decade its remittance will be $\$ 20$ billion. An estimated 1.5 million people join the labor force every year. A significant portion of these workers migrates to countries across the world. According to World Bank report, Bangladeshi migrant worker, who speak little English, have poor basic formal education and few vocational industries specific skills often face severe job insecurities. The lack of knowledge of a foreign language, other than English, is limiting factor. The workforces are, therefore, at a disadvantage when it comes to new job opportunities, especially in our tech-driven world. Bangladeshi migrant's workers earn two times less than Indian peers and three times less than Sri Lankan for the same work just because of their level of skill. Bangladeshis working abroad were hardly educated and skilled. As a result, their wages are very low and they are exploited.

\section{d) Development of infrastructure}

Infrastructure development has many components, including, but not limited to, the development of the following, to name the most obvious items:

\section{- Adequate power supplies on a national scale}

- National roads and highways

- International standard bridges

- Port capacity and increased efficiency

The budget for 2014-2015 has been set against this backdrop to face major economic challenges such as-decelerated economic growth due to stagnant investment, supply side constraints like inadequate infrastructure and deceleration in social sector spending. Infrastructure financing will require billions of dollars. Structuring financing will need a commitment from 3 main stakeholders the private sector, the public sector and the international development partners. The focus should be to encourage public-private partnership, both local and foreign; ensure that the right economic and monetary incentives are created for all parties so that they remain committed and engaged. In this regards, it is crucial to engage experienced professional teams in the early planning stages of the financing structure. The business community will be supportive of any initiative to resolve the infrastructure crisis.

\section{e) Need base IT platform}

IT sector is relatively a young sector in Bangladesh. During the1990 s this sector came to the policy maker glance and has immense prospects. Bangladesh Government declared this sector as trust sector. Bangladesh Government moving forward to Digital Bangladesh. Information and Communication Technology (ICT) is one of the fastest growing sectors in the country. It has been recognized as the key driving force for the socio-economic and industrial development of Bangladesh. Realizing the importance of ICT, the present Government has declared its commitment to take ICT to the door-steps of the wider community and to establish 'Digital Bangladesh' by 2021 through the development and expansion of ICT in the country. But still, need more emphasis on the ICT to spread the benefit in the nation.

\section{f) Integration between Government, Academia and Industry}

There is a lack of integration between the government, academia and industry in Bangladesh. The curriculum in the education institutes is being taught in the same manner as it was taught decades ago though the methods of business have changed drastically. The strategy of three Es - education, employability, and employment have to be taken care off. Total Attendance in early childhood education 2005-2012 of Bangladesh 
is still 14.6\% (2005-2012). (Unicef, 2013) The largest part of Bangladeshi schools is of poor quality. Teachers are not skilled enough. There are problems on the quantitative side too.

\section{g) Flexibility in labor Market and Product Market in Bangladesh}

Bangladesh provides cheap labor and labor market flexibility. It is true that Bangladesh labor market is more flexible than Indian labor market. Labor regulations relaxation can foster higher employment. More firms can enter the organized sector due to increased output and profitability, increasing competition and lowering the prices of formal goods. This helps in increasing the competitiveness of the economy leading to an increase in exports. A relaxation in product market regulations will accelerate investment and increase in output but much relaxation will be required for Bangladesh to outstrip the stagnant GDP growth rate.

h) Providing Rural Prosperity in Agriculture and agrobased industries

Crop agriculture in Bangladesh is constrained every year by challenges, such as a) Loss of Arable Land, b) Population Growth, c) Climate Changes, d) Inadequate Management Practices (fertilizer, water, and pests management), e) Quality Seed Production, f) Credit management, g) Unfair Price of Produces, and h) Insufficient Investment in Agricultural Research. In Bangladesh, about 80,000 ha of arable land is going out of production every year. The loss is alarming and needs to be addressed immediately. The land use policy of the government should be updated and implemented immediately to stop further loss of arable land. (Mondal, 2010)

\section{i) Prioritizing equitable and pro-poor policies}

Income and non-income indicators of poverty, as well as improvements in GDP (both in terms of levels and decreasing volatility), provide evidence of sustained poverty reduction in Bangladesh. However, increases in inequality in the 1990s hindered the extent to which growth benefited the poor. Now Bangladesh has achieved favorable human development conditions at a relatively low level of per capita income. Steadfast, wellorganized infrastructure is critical to economic and social development for promotion of pro-poor growth. Progressive and technologically advanced management of infrastructure investment, increasing the role of infrastructure in the routines of poor people, development of public-private participation model in the rural areas and promoting sector investment, development of cross-sector integration are some of the areas where the government needs to look into so that the poor strata of our society are included in the economic development leading ultimately the achievement of demographic dividend. j) Women's economic, social and political participation

Despite the progress of the last few decades in women's health, education, nutrition, economic opportunities and political participation, women in Bangladesh remain far behind men on these indicators (Rahman 2013). Prevailing socio-cultural perceptions towards women are significant challenges to progress. According to recent World Bank report, Bangladesh is expected to add 1.8 percentage points to GDP growth each year as the number of women joining the country's labor force continue to rise. This will help the country reach to medium-income level by 2021 . The female labor force participation rate would be increased from $34 \%$ to $82 \%$ over the next decade, according to the World Bank Group's women, Business and the law 2016 report. In Bangladesh, women faced genderbased job restrictions.

\section{k) Promotion of good governance}

Good governance as a concept has drawn a sweeping public attention since the 1990s. In Bangladesh, there is a huge difference between the rich and the poor and between the urban areas and rural areas. Also, the disparity exists in the use of scarce natural resources between the corporate and the communities. However, Bangladesh has recognized these issues and has placed the concept of good governance in the 7th Five Year plan. But, at the same time, proper implementation of strategies is required. The successful implementation of good governance nurtures a "development dividend".

\section{I) Rule of law}

In democratic society rule of law is very much accompanied with poverty reduction, development of human capital, empowering women, decentralization and economic development. It is a prerequisite for development. These are the key elements for good governance and sustainable peace building. In Bangladesh, the existing age old legal system is so slow, costly and time-consuming. Sometimes a person takes it as a tool of harassment. Moreover, Fairness is absent in the legal procedure. Due to high population density and extreme inequality in the resource distribution, the law and order situation is deteriorating at an alarming rate and making life increasingly insecure. It is widely believed that well-functioning law and justice institutions and a government bound by the rule of law are important to economic, political and social development. Peaceful conditions in the country develop confidence in the citizens. Effective, timely and impartiality in the justice adds to their confidence. The conclusive, strategic and holistic rule in the law can help in the development of democratic governance. 


\section{POlicy Recommendation}

- To take amenities of the global market, policies for investment have to be formulated to have a long lasting effect.

- $\quad$ The government will need to assist NGOs in moving towards financial sustainability.

- The government should take export strategy for agriculture products, capital goods, and raw materials so that the producer could get incentives.

- Improving educational quality can play a crucial role to widen the major sectors of Bangladesh. So, the government should prioritize to focus on global standard education to enable Bangladesh to compete in the international market.

- Govt. should increase budgetary allocation for SSN program and widen the scope.

- Bangladesh government should expand the vocational training activities as well as the predeparture orientation (PDO) program on technology and foreign language.

- Proper enforcement of Right of Children to Free and Compulsory Education Act has to be done.

- To get the dividend, policies should go beyond antipoverty programs to focus on childcare, transportation and removing legal restrictions on women's work.

- Women's autonomy and decision-making power should be increased by govt. awareness program.

- Govt. need to formulate a proper strategy on agroindustrial linkages, increasing the crop productivity, increased access to agro-industries, providing agricultural credit, having access to advanced technology, developing the wastelands, development of biomass power and biofuels, which in turn can create bountiful opportunities and sustained generation of employment.

- Administrative changes and decentralization, transparency in each department, anticorruption strategies, and strategic assistance to multilateral organizations are some of the matters in which the government has to look deliberately to achieve demographic dividend.

- Law and order and fairness in the effective application should be the top priority of the government of Bangladesh.

\section{Conclusion}

Aboundless supply of young, healthy and educated workers unburdened by both young and old dependents can provide a boost to economic growth, providing the enabling social and economic conditions also subsist. The demographic dividend is not automatic. It is achieved only if the correct human resources policies are pursued. The dividend appears as an addition to the growth that could be expected by capital investment in infrastructure, improved technology, manufacturing plant, or by trade policy, market liberalization etc. If the benefits of the first demographic dividend are attained, per capita income will rise and with more persons economically active, the savings rate will also increase. The policies required to achieve the second demographic dividend are concerned mainly with providing mechanisms and incentives for people to save during their working years.

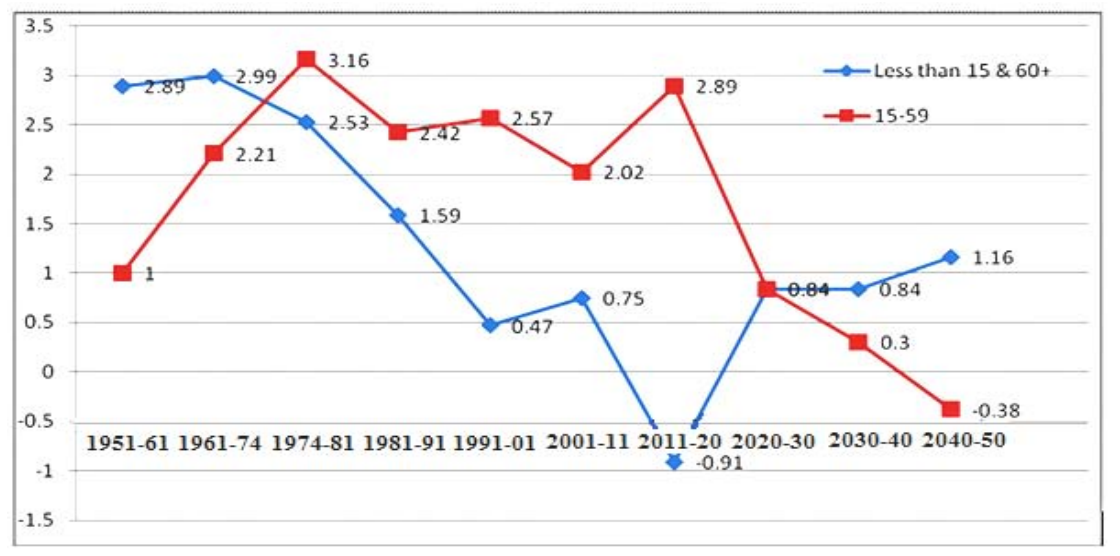

Graph 1 : Trends in growth rate of working age population (15-59) and the growth rate of dependent population (0-14 and above 60 years)

Sources: a. ESCAP- Population of Bangladesh -1981

b. BBS- Population Census -1991

c. BBS- Bangladesh Population Census - 2001

d. UN World Population prospects -2010 revisions

e. BBS- Bangladesh Population and Housing Census -2011 


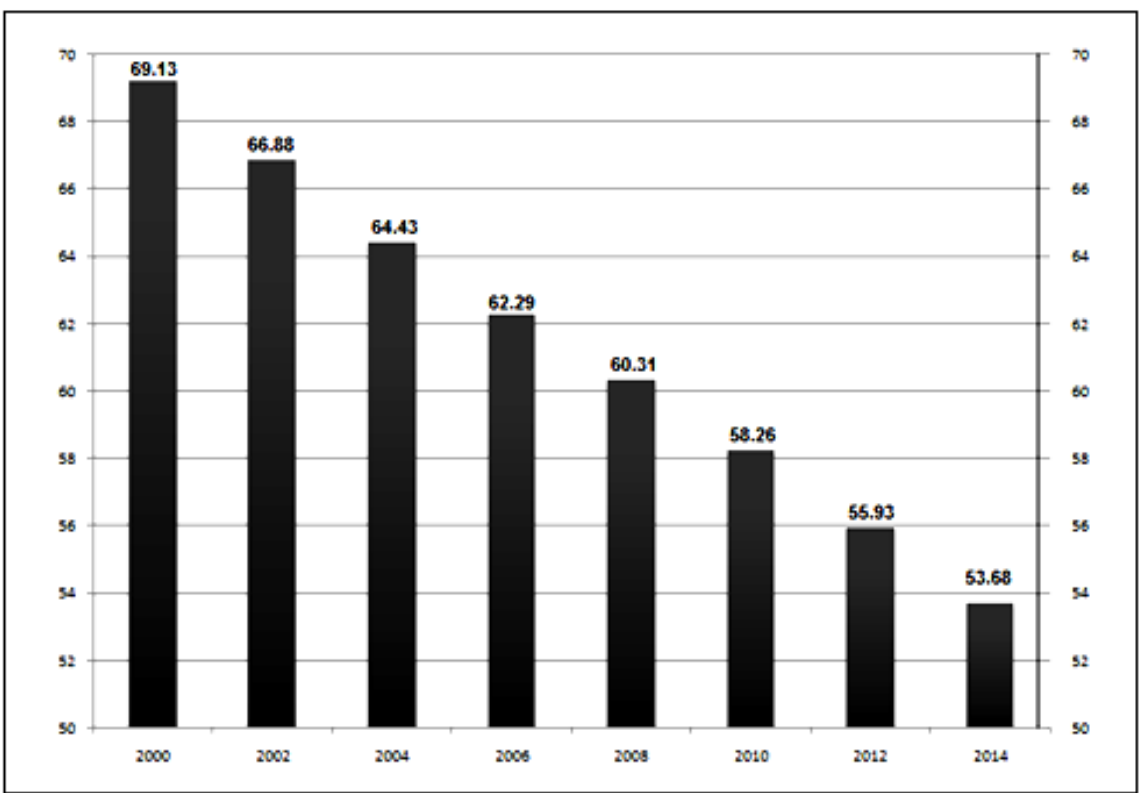

Graph 2 : Age Dependency Ratio (\% of working -age population) in Bangladesh

Source: World Bank Indicators (2014) -Bangladesh Population

Note: Population dependency ratio is defined as 100 - [Population ages 15-64(\% of total)

\section{Table 1 : Components of Population Growth - Custom Region - Bangladesh}

\begin{tabular}{|c|c|c|c|c|c|c|c|c|c|c|c|}
\hline Year & $\begin{array}{l}\text { Birth } \\
\text { Per } \\
1,000 \\
\text { Pop }\end{array}$ & $\begin{array}{l}\text { Death } \\
\text { per } \\
1,000 \\
\text { Pop }\end{array}$ & $\begin{array}{c}\text { Net } \\
\text { No. of } \\
\text { migrants } \\
\text { Per } 1,000 \\
\text { pop }\end{array}$ & $\begin{array}{c}\text { Rate of } \\
\text { natural } \\
\text { increase } \\
(\%)\end{array}$ & $\begin{array}{l}\text { Growth } \\
\text { rate (\%) }\end{array}$ & Population & Births & Deaths & $\begin{array}{l}\text { Net No. of } \\
\text { migrants }\end{array}$ & $\begin{array}{c}\text { Natural } \\
\text { increase }\end{array}$ & $\begin{array}{c}\text { Population } \\
\text { change }\end{array}$ \\
\hline 2000 & 31.1 & 7.4 & -6.3 & 2.3 & 1.7 & $132,150,767$ & $4,112,532$ & 977,916 & $-836,514$ & $3,134,616$ & $2,298,102$ \\
\hline 2010 & 23.4 & 5.8 & -2.1 & 1.8 & 1.6 & $156,118,464$ & $3,657,856$ & 907,048 & $-330,971$ & $2,750,807$ & $2,419,836$ \\
\hline 2014 & 21.6 & 5.6 & 0.0 & 1.6 & 1.6 & $166,280,712$ & $3,593,326$ & 937,823 & $-3,326$ & $2,655,503$ & $2,652,177$ \\
\hline 2025 & 18.2 & 5.6 & 1.8 & 1.3 & 1.4 & $197,673,655$ & $3,597,661$ & $1,112,903$ & 349,882 & $2,484,758$ & $2,834,640$ \\
\hline
\end{tabular}

Note: The growth rate may not equal the sum of the rate of natural increase and the migration rate due to rounding

Source: US Census 2014

Table 2 : Demographic Indicators of Bangladesh

\begin{tabular}{|l|c|c|c|c|c|c|}
\hline \multicolumn{1}{|c|}{ Demographic Indicators } & $\mathbf{1 9 9 5}$ & $\mathbf{2 0 0 5}$ & $\mathbf{2 0 1 4}$ & $\mathbf{2 0 1 5}$ & $\mathbf{2 0 2 5}$ & $\mathbf{2 0 5 0}$ \\
\hline Population & & & & & & \\
\hline Midyear population (in thousands) & 121,442 & 144,139 & 166,281 & 168,958 & 197,674 & 250,155 \\
\hline Growth rate (percent) & 1.6 & 1.7 & 1.6 & 1.6 & 1.4 & 0.6 \\
\hline Fertility & & & & & & \\
\hline Total fertility rate (births per woman) & 3.8 & 3.1 & 2.5 & 2.4 & 2.1 & 2.0 \\
\hline Crude birth rate (per 1,000 population) & 32 & 28 & 22 & 21 & 18 & 13 \\
\hline Births (in thousands) & 3,925 & 3,981 & 3,593 & 3,572 & 3,598 & 3,357 \\
\hline Mortality & & & & & & \\
\hline Life expectancy at birth (years) & 61 & 68 & 70 & 71 & 74 & 79 \\
\hline Infant mortality rate (per 1,000 births) & 92 & 62 & 46 & 44 & 31 & 13 \\
\hline Under 5 mortality rate (per 1,000 births) & 126 & 79 & 57 & 55 & 37 & 15 \\
\hline
\end{tabular}




\begin{tabular}{|l|c|c|c|c|c|c|}
\hline \multicolumn{1}{|c|}{ Demographic Indicators } & $\mathbf{1 9 9 5}$ & $\mathbf{2 0 0 5}$ & $\mathbf{2 0 1 4}$ & $\mathbf{2 0 1 5}$ & $\mathbf{2 0 2 5}$ & $\mathbf{2 0 5 0}$ \\
\hline Crude death rate (per 1,000 population) & 9 & 6 & 6 & 6 & 6 & 8 \\
\hline Deaths (in thousands) & 1,074 & 899 & 938 & 948 & 1,113 & 1,941 \\
\hline Migration & & & & & & \\
\hline Net migration rate (per 1,000 population) & -7 & -5 & -0 & 0 & 2 & -0 \\
\hline Net number of migrants (in thousands) & -901 & -690 & -3 & 78 & 350 & -23 \\
\hline
\end{tabular}

Source: US Census Bureau, 2014
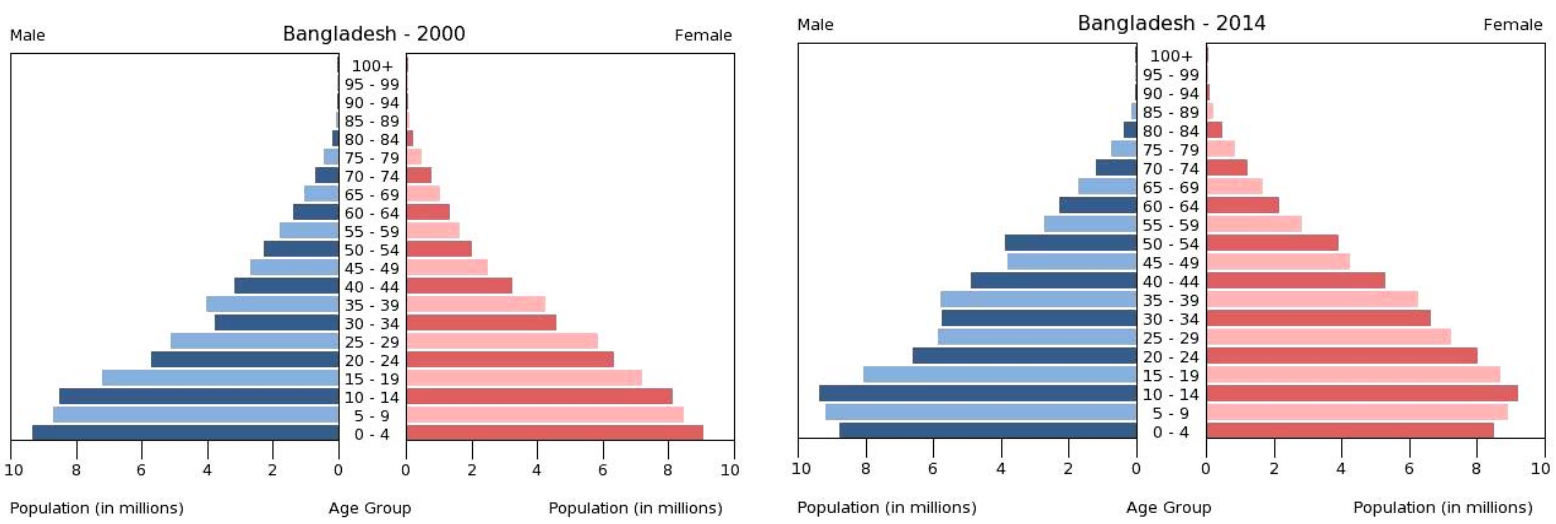

Graph 3 : Bangladesh Demographic Pyramid -2000

Graph 4 : Bangladesh Demographic Pyramid -2014
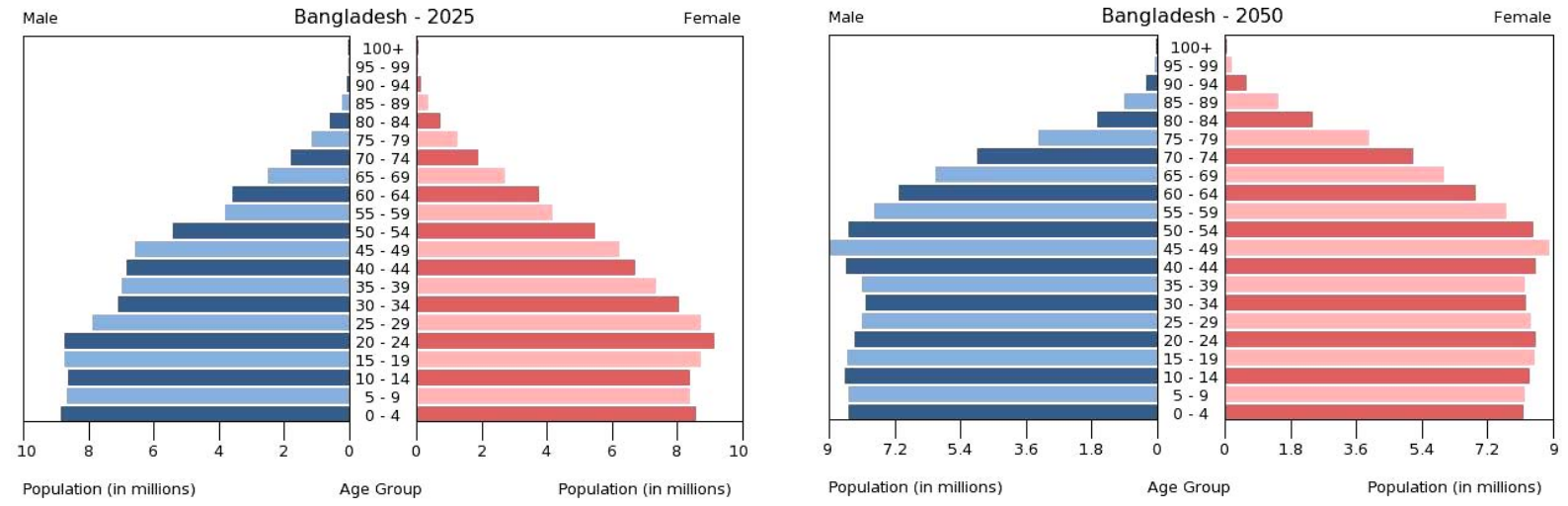

Graph 5 : Bangladesh Demographic Pyramid - 2025

Graph 6 : Bangladesh Demographic Pyramid -2050 Source: US census Bureau 2014

Table 3 : Bangladesh: Evaluation of Poverty

\begin{tabular}{|c|c|c|c|c|c|c|}
\hline Poverty Headcount & & 1992 & 1996 & 2000 & 2005 & 2010 \\
\cline { 2 - 7 } Ratio (in percent) & Urban & 42.7 & 27.8 & 35.2 & 28.4 & 21.2 \\
\cline { 2 - 7 } & Rural & 58.7 & 54.5 & 52.3 & 43.8 & 35.2 \\
\cline { 2 - 7 } & National & 56.6 & 50.1 & 48.9 & 40.0 & 31.5 \\
\hline $\begin{array}{c}\text { Poverty Gap ratio at } \$ 1.25 \text { a day } \\
\text { (PPP) (in percent) }\end{array}$ & 23.8 & 19.2 & 18.6 & 14.1 & 11.1 \\
\hline \multicolumn{2}{|c|}{ Gini Index } & 27.6 & 33.0 & 33.5 & 33.2 & 32.1 \\
\hline
\end{tabular}

\section{References Références Referencias}

1. Bangladesh Bank 2015, Wage earners ' remittance inflow. Available from :< https://www.bb.org.bd/- econdata/wageremitance.php >. [20 September 2015].

2. Bangladesh Bureau of Statistics (BBS). 2011c Report of the Household Income and Expenditure 
Survey. Dhaka: Bangladesh: Bangladesh Bureau of Statistics.

3. Barkat, A, Gupta, SKS, Hussain, AA, Rahman, M, Ahamed, FM, 2013, 'Improving the targeting effectiveness of social safety nets in Bangladesh', Paper presented at Extreme Poverty Research Group (EPRG) 11, Social Protection of the Poorest, Dhaka.

4. Bloom, D.E., D. Canning and P.N. Malaney (2000), Demographic Change and Economic Growth in Asia, Population and Development Review, 26: 257-290.

5. Bloom, D.E., D. Canning and J. Sevilla (2003), The Demographic Dividend: A New Perspective on the Economic Consequences of Population Change, Population Matters, RAND.

6. Centre for Policy Dialogue (CPD). 2008, 'Microeconomic implications of Social Safety Nets in the context of Bangladesh', Paper no. 75, Center for Policy Dialogue, Dhaka, Bangladesh.

7. Coale, A.J. and E.M. Hoover (1958), Population Growth and Economic Development in Low-Income Countries: A Case Study on India's Prospects, Princeton, Princeton University Press.

8. David E. Bloom, David Canning and Jaypee Sevilla (2001) Economic Growth And The Demographic Transition, NBER Working Paper Series, Working Paper 8685, http://www.nber.org/papers/w8685, December 2001.

9. Dr. Swapan Kumar Roy and Suhas Roy, Demographic Dividend In India: A Synoptic View (2014), International Journal of Business and Administration Research Review, Vol.2, Issue.4, pp: 166-175.

10. Easterlin, R.A. (1967), The Effect of Population Growth on Economic Development of Developing Countries, The Annals of the American Academy of Political and Social Sciences, 369: 98-108.

11. Eastwood, R. and M. Lipton (1999), Impact of Changes in Human Fertility on Poverty, Journal of Development Studies, 36(1): 1-30.

12. Ehlrich, P. and A. Ehlrich (1990), The Population Explosion: Why isn't Everyone as Scared as We Are? The Amicus Journal, 12(1): 22-29.

13. Giriyan. S (2015), 'Skill development can further boost remittance', The Independent, 17 September. Available from: <http://www.theindependentbd.com>. [26 October 2015].

14. http://www.dhakatribune.com/business/2015/sep/11 /world-bank-bangladesh-economy-benefit-rising-female-workers

15. Gribble J. and Bremner J. (2012), The Challenge of attaining the Demographic Dividend, Policy Brief, Population Reference Bureau.

16. Mason, A. and S.H. Lee (2004), The Demographic Dividend and Poverty Reduction, November 12.
Available at: http://www2.hawaii.edu/ - amason/Research/mason_popmdg19_rev.pdf

17. Mason, A. (2005), Demographic Dividends: The Past, the Present, and the Future, November 12. Available at: http://www2.hawaii.edu/ amason/Research/Demographic\%20Dividends[1].Kobe.200 5.pdf

18. Mondal H. Mohammad (2010), Crop Agriculture Of Bangladesh: Challenges And Opportunities, Bangladesh J. Agril. Res., 35(2), pp: 235-245.

19. Pool lan (2007), Demographic Dividends: Determinants of Development or Merely Windows of Opportunity?, AGEING HORIZONS, Issue No. 7, pp: 28-35.

20. Rahman, K.M.M. (2013), "Demographic and economic profile of women," in R.A.M. Titumir (ed.) Institutions Matter: The State of Women in Bangladesh. Dhaka: Unnayan Onneshan.

21. Raihan, S. (2013), 'Social protection for inclusive growth: the case of Bangladesh', South Asian Network on Economic Modeling, Dhaka, Bangladesh.

22. Simon, J.L. (1981), The Ultimate Resource, Princeton, Princeton University Press.

23. Tariq Hareem \& Malik A Mani (2012), Demographic Dividend of India-Hit or Miss, Research journals of Economics and Business studies, Volume 1, Number: 06.

24. TC. Prince (2014), The Prospects of Demographic Dividend of India and The Need for Pre-Emptive Policy Initiatives, GJRA - Global Journal For Research Analysis, Volume-3, Issue-7, pp: 92-93.

25. Thompson D. \& Tongo M. (2012), Target of inclusive growth and demographic dividend of India, International Journal of Scientific and Research Publications, Volume 2, Issue 8, pp: 1-3.

26. Unicef, (2013);http://www.unicef.org/infobycountry/bangladesh_bangladesh_statistics.html

27. Unnayan Onneshan (2014), Dealing with Deceleration: the State of Bangladesh Economy and Development 2014, Dhaka: Unnayan Onneshan. World Bank 2014b http://www.data.worldbank.com

28. United States Agency for international Development (2008), "Guide to rule of law Country analysis: The rule of law strategic Framework, A guide for USAID democracy and governance offices, pp: 5-45. 